\title{
二軸対称断面を有する空間片持梁-柱の定常状態限界 THE STEADY-STATE LIMITS OF SPACE CANTILEVER BEAM-COLUMNS WITH A BIAXIAL-SYMMETRICAL CROSS-SECTION
}

\author{
栘井 健*, 上谷宏二** \\ Takeshi MASUI and Koji UETANI
}

\begin{abstract}
A finite element analysis method is proposed for predicting the steady-state limit of a cantilever beamcolumn whose cross-section is symmetrical with respect to two orthogonal axes in a 3D space. The beamcolumn is subjected to an idealized completely reversed tip-deflection cycling program with continuously increasing amplitude under a constant axial load. Firstly, an analysis method is presented for tracing the steady-state path of the beam-column. Secondly, the steady-state limit of a tip deflection amplitude is found as a limit point of a steady-state path. Finally, the steady-state limits are verified through finite element analyses of hysteretic responses of beam-columns.
\end{abstract}

Keywords : beam-columns, cyclic bending, out-of-plane deformation, steady-state limit, finite element method

梁-柱, 繰り返し曲げ, 構面外変形, 定常状態限界, 有限要素法

\section{1. 序}

構面に関して対称な形状を持つ梁-柱に、圧縮軸力を作用させ た状態で繰り返し曲げを与えると、古典理論により予測される横 座屈振幅 ${ }^{1)}$ よりも遥かに小さい曲げ振幅の下で、構面外変形が 発生する。この現象が実際に起こりうることは、 $\mathrm{H}$ 形鋼及び角形 鋼管の梁-柱供試体を用いた一定振幅、あるいは段階的漸增振幅 の繰り返し曲げ実験によって実証されている2,3)。

横座屈条件が満足される以前の段階で構面外変形が現われる ことは、釣合経路の分岐条件に基づく古典座屈理論の範囲では説 明が付けられないが、㑉体と弾塑性ばねで構成された 3 自由度 単純モデルの履歴挙動を解析的方法で検討することにより、繰り 返し載荷の下で構面外変形が現われるメカニズムと発生条件が 解明されている4)。

一定圧縮軸力の作用下で連続的振幅漸増繰り返し曲げを受け る片持梁-柱の挙動においても、載荷構面外への変形が初めて生 じる臨界点が存在し、これを構面内挙動限界と呼ぶ。繰り返し載 荷振幅の増加に連れて連続的に生じる定常状態の変化を定常状 態経路という概念を用いて表すと、構面内挙動限界は定常状態経 路の分岐点となる。筆者等は、三次元空間内での弾塑性大たわみ 挙動を精密に取り扱える梁-柱有限要素法を提案し、これを用い て任意断面形状を持つ梁-柱の構面内挙動限界を必要とされる精 度で予測しうる解析法を展開している5)。

分岐後の定常状態経路が載荷振幅の増加を伴う場合、繰り返 し載荷振幅が構面内挙動限界値を越えた後も梁-柱はなお定常状 態を呈し続け、この過程で、定常状態に含まれる構面外変形成分
は載荷振幅の増加に連れて増大する。やがて載荷振幅が第 2 の 限界值に達すると、挙動はもはや定常状態に収束せず、変形が載 荷サイクル毎に限りなく累積して崩壊に至る現象が現われる。こ の終局的限界点は定常状態限界6-8) と呼ばれ、載荷振幅が極大 値をとる定常状態経路の極限点として特徽付けられる。

本研究では、完全両振り繰り返し曲げを受ける二軸対称断面 梁-柱を対象とし、定常状態限界を求めるための解析法を提示す る。梁-柱の離散モデル化には文献 5) で提案した有限要素法を用 い、解析法の核となる定常状態変化率方程式を誘導する。定常状 態変化率方程式に基づく増分解析を行なって定常状態経路を追跡 し、その極限点として定常状態限界を求める。

この問題では一般に、定常状態限界に至るまでの段階で定常 状態経路が分岐を経験する。構面内挙動限界がこの分岐点となる 場合もあるが、定常状態が構面に直交する平面に関して対称性を 失う臨界点である対称限界が分岐点となる場合もあり得る。分岐 前経路上における定常状態変化率方程式を分析することにより、 分岐解の構造を明らかにする。

解析例として、強軸方向に繰り返し曲げを受ける $\mathrm{H}$ 形鋼片持 梁-柱を取り上げ、定常状態経路の追跡を行ない、定常状態限界 を予測する。予測限界值前後の振幅レベルで、一定振幅繰り返し 載荷を与えたときの全履歴挙動を追跡する解析を行ない、本解析 法の妥当性を検証する。

\section{2. 複合非線形解析のための有限要素方程式}

定常状態経路解析法を展開するためには、高精度の立体骨組 部材の複合非線形解析法が必要となる。立体骨組の複合非線形解

\footnotetext{
本論文の一部は文献15～17)に発表している。

* 関西大学工学部建築学科 助手・工修

** 京都大学大学院工学研究科建築学専攻 教授.工博
}

Research Assoc., Dept. of Architecture, Kansai Univ., M. Eng.

Prof., Dept. of Architecture, Graduate School of Engineering, Kyoto Univ., Dr. Eng. 
析法については、すでにいくつかの解析法が提案されているが $9,10)$ 、本論文では、有限要素法を用いた立体骨組部材の複合非線 形解析法 ${ }^{5)}$ に基づく定式化を行う。この解析法は、以下に示す 仮定に従う。

a) 部材断面の面内形状は変形前後において不変であり、面内 の変形は生じない。

b) Timoshenko 梁理論に従う変形と、材軸回りのねじれ変形 を考慮する。ねじれに伴う断面のそり(断面の面外ゆがみ) は、一様断面弾性梁の均等ねじれに対する St.Venantのね じれ理論により求まるそり関数と、材軸に沿って変化する ねじれ率との積で与えられるものとする ${ }^{11) 。 ~}$

c）有限変位、有限回転角を考慮するが、ひずみは微小である。

d) せん断応力と軸方向応力との連成は考慮せず、材料はそれ ぞれ独立した応力ーひずみ関係に従う。

基礎方程式を、以下の方針に従って導出する。

1) 空間固定の直交デカル卜座標系 $X-Y-Z$ (固定座標系) を考え、初期状態において材軸が $Z$ 軸に一致するよう部材 を配置する。

2) 部材は材軸方向に直列に並ぶ有限要素により構成される (図 7 )。要素両端面の図心に節点 ( $\mathrm{P}$ 点、 $\mathrm{Q}$ 点) をとる。

3) 部材の変形に伴って移動、回転する直交座標系 $x-y-z$ (要素移動座標系) を各要素ごとに配置する。P点を原点と し、 $\mathrm{P}-\mathrm{Q}$ を通る直線を $z$ 軸とする。また、 $\mathrm{P}$ 点を含む有限 要素端面内の任意の点の $(x, y)$ 座標値は常に一定であるよ うに座標系をとる(図 1 )。

4) 各要素は三角柱領域に分割され(図 8 )、応力およびひずみ 状態をその重心点で評価する。

5) 応力: ひずみは、軸方向ひずみおよび 2 個のせん断ひずみ からなるひずみベクトル $\varepsilon^{T}=\left\lfloor\varepsilon \gamma_{z x} \gamma_{z y}\right\rfloor$ と、それに対応

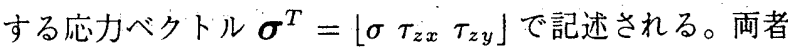
の関係は、せん断成分についてはそれぞれ常に線形弾性を 保ち、軸方向成分のみ塑性変形を考慮し、引張側を正とす るバイリニアひず多硬化則（図 2 )に従うものとする。

6) 要素内のひずみ-変位関係式は線形関係にあるものとする。

$x 、 y 、 z$ 軸方向変位 $u(x, y, z) 、 v(x, y, z) 、 w(x, y, z)$ は、材 軸線変位 $u_{0}(z) 、 v_{0}(z) 、 w_{0}(z)$ と、 $x 、 y$ 軸回りのせん断変形角 $\phi_{x}(z) 、 \phi_{y}(z)$ および $z$ 軸回りのねじれ回転角 $\theta_{0}(z)$ を用いて以 下のように表される。

$$
\begin{aligned}
u(x, y, z)= & u_{0}-y \theta_{0} \\
v(x, y, z)= & v_{0}+x \theta_{0} \\
w(x, y, z)= & w_{0}-x\left(u_{0, z}+\phi_{y}\right) \\
& -y\left(v_{0, z}+\phi_{x}\right)+\theta_{0}, z \omega(x, y)
\end{aligned}
$$

ここに、 $\omega(x, y)$ は St.Venantねじれに伴うそり関数、( ), ${ }_{z}$ は $z$ による微分を表す。 $w_{0}(z) 、 \phi_{x}(z) 、 \phi_{y}(z)$ をそれぞれ 1 次式に ようて近似し、 $u_{0}(z) 、 v_{0}(z) 、 \theta_{0}(z)$ をそれぞれ 3 次式によって

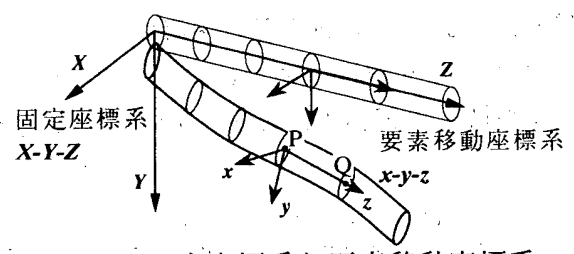

図 1 固定座標系と要素移動座標系

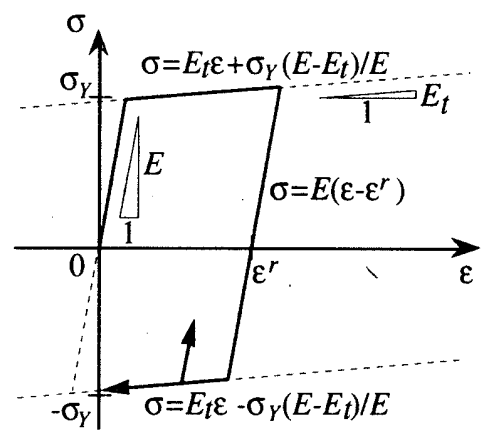

図 2 応力-ひずみ関係

近似する。 $x 、 y$ 軸回りの断面のせん断変形角とたわみ角に関し ては、文献 12) で示された縮䄪法を用いて境界条件を厳密に取 り扱っており、両者の值に力学的な矛盾は生じない。

節点変位ベクトルUは次式で表される注1)。

$$
\begin{aligned}
& \mathbf{U}^{T}=\left\lfloor\begin{array}{lllllll}
U_{P} & W_{P} & \Theta_{y P} & V_{P} & \Theta_{x P} & \Theta_{z P} & \alpha_{P}
\end{array}\right.
\end{aligned}
$$

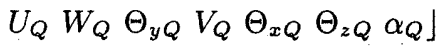

ここに、 $U 、 V 、 W$ は $X 、 Y 、 Z$ 軸方向の変位を表す。 $\Theta_{z} 、 \Theta_{x}$ 、 $\Theta_{y}$ は回転変位を表し、初期状態加ら $Z 、 X 、 Y$ 軸回りにその順 番で回転して現状態に至るために必要な回転量として定義され $ろ^{5)}$ 。 $\alpha$ は $z$ 軸回りの回転率を表す。

節点力ベクトル $\mathbf{F}$ は次式で表される。

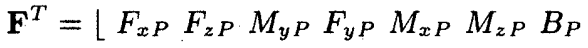

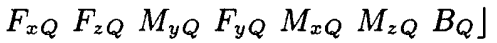

ここに、Fはそれぞれの座標方向の力、 $M$ はそれぞれの座標軸 まわりのモーメント、Bはバイモーメントを表す。

式 (3) の節点力ベクトルが仕事をする相手として対応する仮 想変位ベクトルを次式で表す5)。

$$
\begin{aligned}
& \delta \hat{\mathbf{U}}^{T}=\left\lfloor\delta U_{P} \delta W_{P} \delta \hat{\Theta}_{y P} \delta V_{P} \delta \hat{\Theta}_{x P} \delta \hat{\Theta}_{z P} \delta \alpha_{P}\right. \\
& \left.\delta U_{Q} \delta W_{Q} \delta \hat{\Theta}_{y Q} \delta V_{Q} \delta \hat{\Theta}_{x Q} \delta \hat{\Theta}_{z Q} \delta \alpha_{Q}\right\rfloor
\end{aligned}
$$

ここに、 $\delta \hat{\Theta}_{x} 、 \delta \hat{\Theta}_{y} 、 \delta \hat{\Theta}_{z}$ は、現状態加の固定座標軸回りの回 転角についての仮想回転変位である。

要素が節点力 $\mathbf{F}$ の作用下で鈎り合っているとき、次の仮想仕 事式が成立する。

$$
\delta \hat{\mathbf{U}}^{T} \mathbf{F}=\int_{0}^{l} \int_{a} \delta \varepsilon^{T} \boldsymbol{\sigma} d a d l
$$

ここに、lは要素長、 $a$ は断面積を表す。

\section{3. 定常状態経路解析法}

\section{1 基本概念と基本方針}

幾何学的形状拈よび力学的性質が $X-Z$ 平面および $Y-Z$ 平 面に関して対称性を有する片持梁-柱モデルを解析対象とする。こ の二つの対称面をそれぞれ構面および直交対称面と呼ぶ (図 3 )。

載荷は以下の通りである。

1) 0 から連続的に単調増加する振幅パラメター $\Psi$ を定め、そ の各振幅レベルで同一振幅の繰り返し載荷を定常状態に収 束するまで行う強制変位載荷プログラム COIDAを定義す る(図 4 )。

2) 片持梁-柱頂点に一定鉛直荷重 $N$ を作用させる。

3) 片持梁-柱頂点に、COIDAに従う片側振幅 $\Psi$ の $X$ 方向変 位 $U_{T}$ を作用させる。以下、この $U_{T}$ を制御変位と呼ぶ。な お、頂点の $Y 、 Z$ 方向の変位成分および $X 、 Y 、 Z$ 軸回り の回転変位成分は自由とする。 


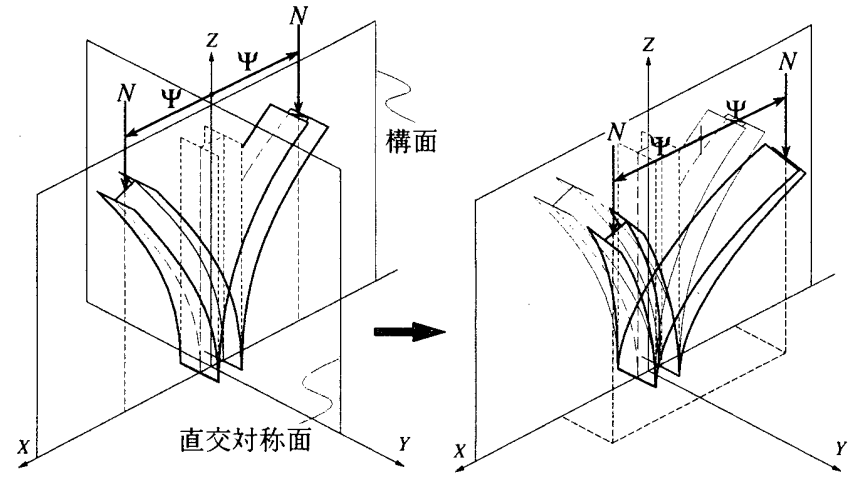

図 3 二軸対称断面片持梁-柱の構面外変形発生挙動
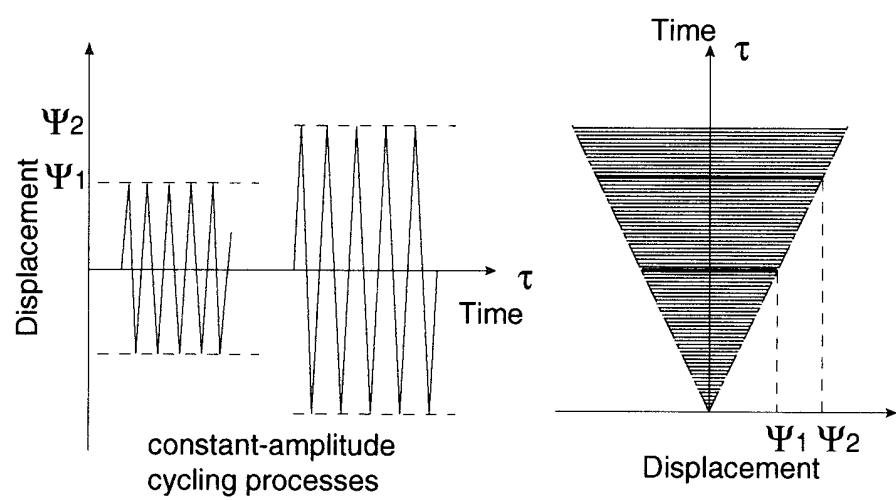

図 4 COIDA program

ここで、応力、ひずみ状態の定常応答に関して、次の仮定 ${ }^{5-7)}$ を導入する。

仮定 1: 「ひずみ進行方向の反転が生じるのは、制御変位の進行 方向が反転する瞬間のみである。」

$U_{T}=\Psi$ の反転時状態を $\Gamma^{I}$ 状態、 $U_{T}=-\Psi$ の反転時状態を $\Gamma^{I I}$ 状態と呼ぶ。仮定 1 より、1 個の定常状態は、これら一対の

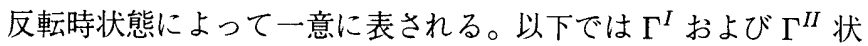
態に属する状態量を右上添字 $I 、 I I$ を用いて表す。

本論文で用いる基本概念を以下に示す。

構面内定常状態: 初期状態において構面に関して互いに対称な位 置にある任意の 2 点における全ての状態量が、常に構面に関し て対称である定常状態。

構面外定常状態: 構面内定常状態以外の定常状態。すなわち、構 面に関する対称性を有さない定常状態。

対称定常状態: $\Gamma^{I}$ 状態と $\Gamma^{I I}$ 状態が、直交対称面に関して互い に対称である定常状態。

非対称定常状態: 対称定常状態以外の定常状態。すなわち、直交 対称面に関する対称性を有さない定常状態。

構面内挙動限界: 構面内定常状態から構面外定常状態への移行が 初めて生じる臨界点。

対称限界: 対称定常状態から非対称定常状態への移行が初めて生 じる臨界点。

定常状態限界: いかなる定常状態にも収束しなくなり、変形の発 散が初めて生じる臨界点。

定常状態限界解を求める基本方針を以下に示す。

1) 制御変位振幅 $\Psi$ の変化に伴って、梁-柱の定常状態は連続的 に変化する。定常状態变数である反転時節点変位および節 点力について、それらの $\Psi$ に対する変化率の関係式を導く。

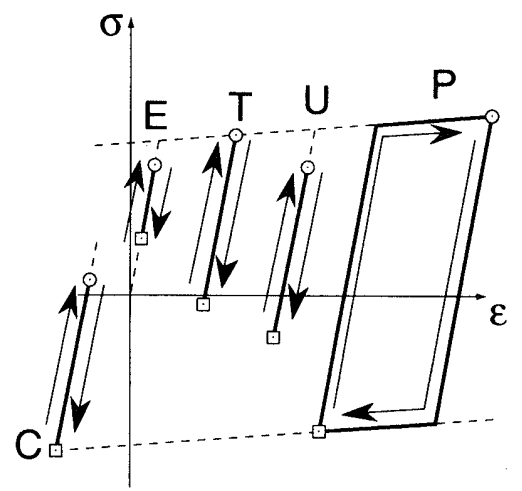

図 5 応力-ひずみ状態点の定常状態周期挙動

2) 各定常状態変数について、構面内対称成分、構面内逆対称 成分、構面外対称成分および構面外逆対称成分の 4 成分を 定義する。これに対応して、1)で求めた式をこの 4 成分に ついての方程式に変換する。構面内対称定常状態において は、変換された方程式が、これら４成分の連成項を含まず、 それぞれの成分だけを単独に含む 4 種類の独立した式で表 されることが証明される。

3）構面内対称成分についての変化率方程式を用いた増分型解 析法により構面内対称定常状態を逐次追跡する注2)。

4) 構面内対称成分以外の 3 成分に関する変化率方程式は全て 斉次方程式となる。構面内対称定常状態経路上において、各 方程式が非 0 解を初めて持ちうる条件より、3 種類の限界 解がそれぞれ得られる。これらは、対称限界解と 2 種類の 構面内挙動限界解として特徵づけられる。

以下、構面内挙動限界に早期に至る場合について述べる。

5) 構面内挙動限界点は定常状態経路の分岐点であり、構面内 挙動限界点後の分岐経路の方向を分岐モード解析により求 める。 $\Psi$ が減少する方向に分岐経路が存在する場合、構面 内挙動限界点はただちに定常状態限界点となる。

6） $\Psi$ が増加する方向に分岐経路が存在する場合、引続き分岐 後経路解析を行うことができる。定常状態限界は定常状態 経路の極限点として得られる。これを求めるには、通常の 釣合経路の極限点を求める場合と類似の方法をとる。すな わち、増分解析によって定常状態経路を追跡し、 $\Psi$ が極大 值をとる点を求める。

\section{2 定常状態変化率方程式}

梁-柱が定常状態にあるとき、梁-柱内の全ての微小要素での応 力ーひずみ状態点は周期挙動を呈する。この周期挙動の分類を図 5 に示す。図中、○印およびロ印はそれぞれ次に示す応力ひず み状態点を表す。

a) 制御変位進行方向の符号とひずみ進行方向の符号が一致す る場合

$\bigcirc: \Gamma^{I}$ 状態、 $\square: \Gamma^{I I}$ 状態

b) 制御変位進行方向の符号とひずみ進行方向の符号が反対の 場合

$$
\bigcirc: \Gamma^{I I} \text { 状態、 } \square: \Gamma^{I} \text { 状態 }
$$

反転時応力変化率 $\dot{\sigma}^{I} 、 \dot{\sigma}^{I I}$ とひずみ変化率 $\dot{\varepsilon}^{I} 、 \dot{\varepsilon}^{I I}$ の関係は次 式で表される。

$$
\dot{\sigma}^{I}=\tilde{D}_{11} \dot{\varepsilon}^{I}+\tilde{D}_{12} \dot{\varepsilon}^{I I}, \quad \dot{\sigma}^{I I}=\tilde{D}_{21} \dot{\varepsilon}^{I}+\tilde{D}_{22} \dot{\varepsilon}^{I I}
$$


表 1 応力変化率-ひずみ変化率関係式の係数

\begin{tabular}{ccccc}
\hline Type & $\tilde{D}_{11}$ & $\tilde{D}_{12}$ & $\tilde{D}_{21}$ & $\tilde{D}_{22}$ \\
\hline $\mathrm{E} \rightarrow \mathrm{E}$ & $E$ & 0 & 0 & $E$ \\
$\mathrm{~T} \rightarrow \mathrm{T}$ & $E_{t}$ & 0 & $E_{t}-E$ & $E$ \\
$\mathrm{~T} \rightarrow \mathrm{U}$ & $E$ & 0 & 0 & $E$ \\
$\mathrm{C} \rightarrow \mathrm{C}$ & $E$ & $E_{t}-E$ & 0 & $E_{t}$ \\
$\mathrm{C} \rightarrow \mathrm{U}$ & $E$ & 0 & 0 & $E$ \\
$\mathrm{P} \rightarrow \mathrm{P}$ & $E_{t}$ & 0 & 0 & $E_{t}$ \\
\hline
\end{tabular}

ここに、( $)=d() / d \Psi$ 。係数 $\tilde{D}$ は表 1 に示すように、現状態か らの周期挙動の状態変化パターンに応心゙て決定される。式 (6)は a)の場合に適用され、b)の場合は、 $I$ とIIを入れ換えた式が適 用される。

ひずみ-要素内変位関係式、要素内変位-節点変位関係式および 節点変位-付加節点変位関係式を考慮して式 (5)の $\Psi$ に関する増 分型の仮想仕事式を求め、得られた式に式 (6) を代入することに より、定常状態変化率方程式が次式のように得られる

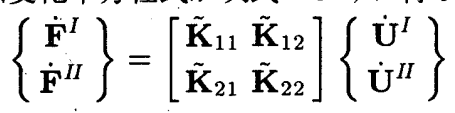

\section{3 定常状態変化率方程式の分離}

$\Gamma^{I}$ 状態、 $\Gamma^{I I}$ 状態に関わらず、 $U, W, \Theta_{Y}$ は構面内成分であり、 $V, \Theta_{X}, \Theta_{Z}, \alpha$ は構面外成分である。このことを考慮して、以下 の式により 4 種類の変位速度成分を定義する。

構面内対称成分： $\dot{\mathbf{U}}^{f i}$

$$
\begin{aligned}
\dot{U}^{f} & =\left(\dot{U}^{I}-\dot{U}^{I I}\right) / 2 \\
\dot{W}^{f} & =\left(\dot{W}^{I}+\dot{W}^{I I}\right) / 2 \\
\dot{\Theta}_{y}^{f} & =\left(\dot{\Theta}_{y}^{I}-\dot{\Theta}_{y}^{I I}\right) / 2
\end{aligned}
$$

構面内逆対称成分 : $\dot{\mathrm{U}}^{b i}$

$$
\begin{aligned}
\dot{U}^{b} & =\left(\dot{U}^{I}+\dot{U}^{I I}\right) / 2 \\
\dot{W}^{b} & =\left(-\dot{W}^{I}+\dot{W}^{I I}\right) / 2 \\
\dot{\Theta}_{y}^{b} & =\left(\dot{\Theta}_{y}^{I}+\dot{\Theta}_{y}^{I I}\right) / 2
\end{aligned}
$$

構面外対称成分： $\dot{U}^{f o}$

$$
\begin{aligned}
& \dot{V}^{f}=\left(\dot{V}^{I}+\dot{V}^{I I}\right) / 2 \\
& \dot{\Theta}_{x}^{f}=\left(\dot{\Theta}_{x}^{I}+\dot{\Theta}_{x}^{I I}\right) / 2 \\
& \dot{\Theta}_{z}^{f}=\left(\dot{\Theta}_{z}^{I}-\dot{\Theta}_{z}^{I I}\right) / 2 \\
& \dot{\alpha}^{f}=\left(\dot{\alpha}^{I}-\dot{\alpha}^{I I}\right) / 2
\end{aligned}
$$

構面外逆対称成分 : $\dot{\mathbf{U}}^{b o}$

$$
\begin{aligned}
\dot{V}^{b} & =\left(-\dot{V}^{I}+\dot{V}^{I I}\right) / 2 \\
\dot{\Theta}_{x}^{b} & =\left(-\dot{\Theta}_{x}^{I}+\dot{\Theta}_{x}^{I I}\right) / 2 \\
\dot{\Theta}_{z}^{b} & =\left(\dot{\Theta}_{z}^{I}+\dot{\Theta}_{z}^{I I}\right) / 2 \\
\dot{\alpha}^{b} & =\left(\dot{\alpha}^{I}+\dot{\alpha}^{I I}\right) / 2
\end{aligned}
$$

節点力についてもこれらに対応する成分 $\dot{\mathbf{F}}^{f i}, \dot{\mathbf{F}}^{b i}, \dot{\mathbf{F}}^{f o}, \dot{\mathbf{F}}^{b o}$ を同 様に定義できる。対称成分および逆対称成分に関する節点変位速 度ベクトルおよび節点力速度ベクトルは以下のように表される。

$$
\begin{aligned}
\dot{\mathbf{U}}^{f^{T}} & =\left\{\dot{\mathbf{U}}_{P}^{f i^{T}} \dot{\mathbf{U}}_{P}^{f o^{T}} \dot{\mathbf{U}}_{Q}^{f i^{T}} \dot{\mathbf{U}}_{Q}^{f o^{T}}\right\} \\
\dot{\mathbf{U}}^{b^{T}} & =\left\{\dot{\mathbf{U}}_{P}^{b i^{T}} \dot{\mathbf{U}}_{P}^{b o} \dot{\mathbf{U}}_{Q}^{b i^{T}} \dot{\mathbf{U}}_{Q}^{b o^{T}}\right\} \\
\dot{\mathbf{F}}^{f^{T}} & =\left\{\dot{\mathbf{F}}_{P}^{f^{T} T} \dot{\mathbf{F}}_{P}^{f o^{T}} \dot{\mathbf{F}}_{Q}^{f T^{T}} \dot{\mathbf{F}}_{Q}^{f o^{T}}\right\} \\
\dot{\mathbf{F}}^{b^{T}} & =\left\{\dot{\mathbf{F}}_{P}^{b^{T} T} \dot{\mathbf{F}}_{P}^{b^{T} T} \dot{\mathbf{F}}_{Q}^{b i^{T}} \dot{\mathbf{F}}_{Q}^{b o^{T}}\right\}
\end{aligned}
$$

式 (8)〜 (11) および対応する節点力の式は次式で表される。

$$
\begin{aligned}
& \left\{\begin{array}{c}
\dot{\mathbf{U}}^{f} \\
\hdashline \mathbf{U}^{b}
\end{array}\right\}=\frac{1}{2}\left[\begin{array}{c:c}
\mathbf{I} & \mathbf{H} \\
\hdashline-\mathbf{H} & \mathbf{I}
\end{array}\right]\left\{\begin{array}{c}
\dot{\mathbf{U}}^{I} \\
\hdashline \mathbf{U}^{I I}
\end{array}\right\} \\
& \left\{\begin{array}{c}
\dot{\mathbf{F}}^{f} \\
\hdashline \mathbf{F}^{b}
\end{array}\right\}=\frac{1}{2}\left[\begin{array}{c:c}
\mathbf{I} & \mathbf{H} \\
\hdashline-\mathbf{H} & \mathbf{I}
\end{array}\right]\left\{\begin{array}{c}
\dot{\mathbf{F}}^{I} \\
\hdashline \mathbf{F}^{I I}
\end{array}\right\}
\end{aligned}
$$

ここに、

$$
\begin{gathered}
\mathbf{H}=\left[H_{i j}\right] \quad(i, j=1, \cdots, 14) \\
H_{i i}=\left\{\begin{array}{ll}
1 & (\mathrm{i}=2,4,5,9,11,12) \\
-1 & (\mathrm{i}=1,3,6,7,8,10,13,14)
\end{array}, H_{i j}=0(i \neq j)\right.
\end{gathered}
$$

I 14 次の単位行列である。

$\mathbf{H}^{-1}=\mathbf{H}$ であるので、式 (16),(17) の逆関係は次式となる。

$$
\begin{aligned}
& \left\{\begin{array}{c}
\dot{\mathbf{U}}^{I} \\
\hdashline \mathbf{U}^{I I}
\end{array}\right\}=\left[\begin{array}{c:c}
\mathbf{I} & -\mathbf{H} \\
\hdashline \mathbf{H} & \mathbf{I}
\end{array}\right]\left\{\begin{array}{c}
\dot{\mathbf{U}}^{f} \\
\hdashline \mathbf{U}^{b}
\end{array}\right\} \\
& \left\{\begin{array}{c}
\dot{\mathbf{F}}^{I} \\
\hdashline \mathbf{F}^{I I}
\end{array}\right\}=\left[\begin{array}{c:c}
\mathbf{I} & -\mathbf{H} \\
\hdashline \mathbf{H} & \mathbf{I}
\end{array}\right]\left\{\begin{array}{c}
\dot{\mathbf{F}}^{f} \\
\hdashline \mathbf{F}^{b}
\end{array}\right\}
\end{aligned}
$$

式 (19),(17) より、式 (7) は、対称成分、逆対称成分に関する 変化率方程式に変換される。

$$
\begin{aligned}
\left\{\begin{array}{c}
\dot{\mathbf{F}}^{f} \\
\dot{\mathbf{F}}^{b}
\end{array}\right\}= & \frac{1}{2}\left[\begin{array}{cc}
\mathbf{I} & \mathbf{H} \\
-\mathbf{H} & \mathbf{I}
\end{array}\right]\left[\begin{array}{ll}
\tilde{\mathbf{K}}_{11} & \tilde{\mathbf{K}}_{12} \\
\tilde{\mathbf{K}}_{21} & \tilde{\mathbf{K}}_{22}
\end{array}\right]\left[\begin{array}{cc}
\mathbf{I} & -\mathbf{H} \\
\mathbf{H} & \mathbf{I}
\end{array}\right]\left\{\begin{array}{l}
\dot{\mathbf{U}}^{f} \\
\dot{\mathbf{U}}^{b}
\end{array}\right\} \\
= & \frac{1}{2}\left[\begin{array}{c}
\tilde{\mathbf{K}}_{11}+\mathbf{H} \tilde{\mathbf{K}}_{21}+\tilde{\mathbf{K}}_{12} \mathbf{H}+\mathbf{H} \tilde{\mathbf{K}}_{22} \mathbf{H} \\
-\mathbf{H} \tilde{\mathbf{K}}_{11}+\tilde{\mathbf{K}}_{21}-\mathbf{H} \tilde{\mathbf{K}}_{12} \mathbf{H}+\tilde{\mathbf{K}}_{22} \mathbf{H} \\
\\
\quad-\tilde{\mathbf{K}}_{11} \mathbf{H}-\mathbf{H} \tilde{\mathbf{K}}_{21} \mathbf{H}+\tilde{\mathbf{K}}_{12}+\mathbf{H} \tilde{\mathbf{K}}_{22} \\
\mathbf{H} \tilde{\mathbf{K}}_{11} \mathbf{H}-\tilde{\mathbf{K}}_{21} \mathbf{H}-\mathbf{H} \tilde{\mathbf{K}}_{12}+\tilde{\mathbf{K}}_{22}
\end{array}\right]\left\{\begin{array}{l}
\dot{\mathbf{U}}^{f} \\
\dot{\mathbf{U}}^{b}
\end{array}\right\}
\end{aligned}
$$

今、現状態が構面内対称定常状態である場合を考える。この 状態は対称定常状態であり、繰り返し載荷についても直交対称面 に関して対称であるから、片持梁-柱の挙動変化には直交对称面 に関して対称性を有するものが必ず存在する。すなわち、式 (7) を梁-柱全体について重ね合わせ、境界条件を代入して得られる 系方程式は、直交対称面に関して対称性を有する自明解を持つ。 自明解の要素節点変位、節点力成分 $\dot{\mathbf{U}}^{I^{*}}, \dot{\mathbf{U}}^{I I^{*}}, \dot{\mathbf{F}}^{I^{*}}, \dot{\mathbf{F}}^{I I^{*}}$ は次式 の関係を持つ。

$$
\mathbf{H} \dot{\mathbf{U}}^{I I^{*}}=\dot{\mathbf{U}}^{I^{*}}, \mathbf{H} \dot{\mathbf{F}}^{I I^{*}}=\dot{\mathbf{F}}^{I^{*}}
$$

式 (22) は、次式と同じ意味である。

$$
\dot{\mathrm{U}}^{f^{*}} \neq \mathbf{0}, \quad \dot{\mathbf{U}}^{b^{*}}=\mathbf{0}, \quad \dot{\mathbf{F}}^{f^{*}} \neq \mathbf{0}, \quad \dot{\mathbf{F}}^{b^{*}}=\mathbf{0}
$$

式 (22)を式 (7)に代入すると、次の関係式が導ける。

$$
\tilde{\mathbf{K}}_{11}+\tilde{\mathbf{K}}_{12} \mathbf{H}=\mathbf{H} \tilde{\mathbf{K}}_{22} \mathbf{H}+\mathbf{H} \tilde{\mathbf{K}}_{21}
$$

現状態が何らかの臨界点にある場合には式 (24) は自明ではな く、成立しない可能性が残る。しかしながら、この可能性は、以 下の考察を行うことによって否定される。

全ての定常状態変数は $\Psi$ に関する連続関数である。従って、

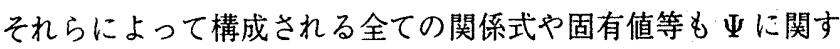
る連続性を有する注3)。また、式 (24) は、臨界点の前後の正則点 においては明らかに成立する。従って、関数の連続性より、臨界 点においても式 (24) は成立する。

式 (24) を式 (21) に代入すると次式を得る。

$$
\left\{\begin{array}{c}
\dot{\mathbf{F}}^{f} \\
\dot{\mathbf{F}}^{b}
\end{array}\right\}=\left[\begin{array}{cc}
\tilde{\mathbf{K}}_{11}+\tilde{\mathbf{K}}_{12} \mathbf{H} & \mathbf{0} \\
\mathbf{0} & \mathbf{H} \tilde{\mathbf{K}}_{11} \mathbf{H}-\mathbf{H} \tilde{\mathbf{K}}_{12}
\end{array}\right]\left\{\begin{array}{l}
\dot{\mathbf{U}}^{f} \\
\dot{\mathbf{U}}^{b}
\end{array}\right\}
$$

従って、式 (21) は、対称成分、逆対称成分に関する独立した 2 組の方程式に分離される。

$$
\begin{aligned}
\dot{\mathbf{F}}^{f} & =\left(\tilde{\mathbf{K}}_{11}+\tilde{\mathbf{K}}_{12} \mathbf{H}\right) \dot{\mathbf{U}}^{f}=\tilde{\mathbf{K}}^{f} \dot{\mathbf{U}}^{f} \\
\dot{\mathbf{F}}^{b} & =\left(\mathbf{H} \tilde{\mathbf{K}}_{11} \mathbf{H}-\mathbf{H} \tilde{\mathbf{K}}_{12}\right) \dot{\mathbf{U}}^{b}=\tilde{\mathbf{K}}^{b} \dot{\mathbf{U}}^{b}
\end{aligned}
$$


次に、構面内成分および構面外成分に着目すれば、式 (26),(27) はそれぞれ以下のように表現できる。

$$
\begin{array}{r}
\left\{\begin{array}{c}
\dot{\mathbf{F}}^{f i} \\
\hdashline \mathbf{F}^{f o}
\end{array}\right\}=\left[\begin{array}{c:c}
\tilde{\mathbf{K}}^{f i} & \tilde{\mathbf{K}}^{f i o} \\
\hdashline \mathbf{K}^{f o i} & \dot{\mathbf{K}}^{f o}
\end{array}\right]\left\{\begin{array}{c}
\dot{\mathbf{U}}^{f i} \\
\hdashline \mathbf{U}^{f o}
\end{array}\right\} \\
\left\{\begin{array}{c}
\dot{\mathbf{F}}^{b i} \\
\hdashline \mathbf{F}^{b o}
\end{array}\right\}=\left[\begin{array}{c:c}
\tilde{\mathbf{K}}^{b i} & \tilde{\mathbf{K}}^{b i o} \\
\hdashline \tilde{\mathbf{K}}^{b o i} & \mathbf{K}^{b o}
\end{array}\right]\left\{\begin{array}{c}
\dot{\mathbf{U}}^{b i} \\
\hdashline \mathbf{U}^{b o}
\end{array}\right\}
\end{array}
$$

現状態は構面内定常状態でもあり、このとき繰り返し載荷は 構面内に作用するので、片持梁-柱の挙動変化には構面外成分が 0であるものが必ず存在する。すなわち、式 (28),(29) 梁-柱全 体について重ね合わせ、境界条件を代入して得られる系方程式

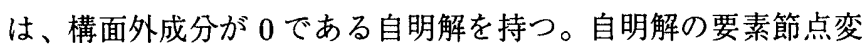
位、節点力成分は次式の関係を持つ。

$$
\begin{aligned}
& \dot{\mathbf{U}}^{f i^{*}} \neq \mathbf{0}, \quad \dot{\mathbf{U}}^{f o^{*}}=\mathbf{0}, \quad \dot{\mathbf{F}}^{f i^{*}} \neq \mathbf{0}, \quad \dot{\mathbf{F}}^{f o^{*}}=\mathbf{0} \\
& \dot{\mathbf{U}}^{b i^{*}} \neq \mathbf{0}, \quad \dot{\mathbf{U}}^{b o^{*}}=\mathbf{0}, \quad \dot{\mathbf{F}}^{b i^{*}} \neq \mathbf{0}, \quad \dot{\mathbf{F}}^{b o^{*}}=\mathbf{0}
\end{aligned}
$$

従って、式 (28),(29) の係数について次式が成り立つ。

$$
\tilde{\mathbf{K}}^{f i o}=\mathbf{0}, \quad \tilde{\mathbf{K}}^{f o i}=\mathbf{0}, \quad \tilde{\mathbf{K}}^{b i o}=\mathbf{0}, \quad \tilde{\mathbf{K}}^{b o i}=\mathbf{0}
$$

式 (32) の成立に関しても、式 (24) の場合と同様の考察を行うこ とができる。

結局、式 (21) は、4 組の独立な方程式に帰着する。

$$
\begin{aligned}
& \text { 構面内対称成分 }: \dot{\mathbf{F}}^{f i}=\tilde{\mathbf{K}}^{f i} \dot{\mathbf{U}}^{f i} \\
& \text { 構面外対称成分 : } \dot{\mathbf{F}}^{f o}=\tilde{\mathbf{K}}^{f o} \dot{\mathbf{U}}^{f o} \\
& \text { 構面内逆対称成分： } \dot{\mathbf{F}}^{b i}=\tilde{\mathbf{K}}^{b i} \dot{\mathbf{U}}^{b i} \\
& \text { 構面外逆対称成分： } \dot{\mathbf{F}}^{b o}=\tilde{\mathbf{K}}^{b o} \dot{\mathbf{U}}^{b o}
\end{aligned}
$$

\section{4 定常状態経路解析}

要素方程式 $(33) \sim(36)$ を梁-柱全体について重ね合わせて 4 組 の系方程式をつくる。

$$
\begin{aligned}
& \text { 構面内対称成分 }: \dot{\mathbf{F}}_{G}^{f i}=\tilde{\mathbf{K}}_{G}^{f i} \dot{\mathbf{U}}_{G}^{f i} \\
& \text { 構面外対称成分 }: \dot{\mathbf{F}}_{G}^{f o}=\tilde{\mathbf{K}}_{G}^{f o} \dot{\mathbf{U}}_{G}^{f o} \\
& \text { 構面内逆対称成分 }: \dot{\mathbf{F}}_{G}^{b i}=\tilde{\mathbf{K}}_{G}^{b i} \dot{\mathbf{U}}_{G}^{b i} \\
& \text { 構面外逆対称成分 }: \dot{\mathbf{F}}_{G}^{b o}=\tilde{\mathbf{K}}_{G}^{b o} \dot{\mathbf{U}}_{G}^{b o}
\end{aligned}
$$

式 (37) を境界条件の下に解き、構面内対称定常状態の増分解 を求めることができる。これを累加していくことにより、基本経 路である構面内対称定常状態経路を追跡できる。一方、式 (38) 〜 (40) の指定変位成分、指定力成分は全て 0 であるので、斉次 方程式となり、 $\dot{\mathrm{U}}_{G}^{f o}=0 、 \dot{\mathrm{U}}_{G}^{b i}=0 、 \dot{\mathrm{U}}_{G}^{b o}=0$ を自明解として 持つ。

ここで、塑性体についての釣合経路の唯一性と安定性に関す

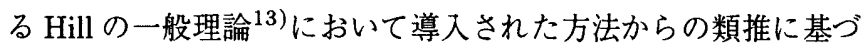
き、応力、ひずみ状態の定常応答に関して、次の仮定 ${ }^{5-7) を さ ら ~}$ に導入する。

仮定 2: 「構面内定常状態から構面外定常状態へ移行が生じる瞬 間あるいは対称定常状態から非対称定常状態へ移行が生じる瞬 間には、C $\rightarrow U$ または $\mathrm{T} \rightarrow U$ の定常状態周期挙動の変化は梁-柱 内のどの微小要素においても生じない。」(C、U、Tの記号につ いては図 5 参照。)

仮定 2 に基づいて選定、評価された式 (6) の係数 $\tilde{D}$ を用いて 式 $(38) \sim(40)$ の係数 $\tilde{\mathbf{K}}_{G}^{f o} 、 \tilde{\mathbf{K}}_{G}^{b i} 、 \tilde{\mathbf{K}}_{G}^{b o}$ は計算され、それぞれに ついて变位速度の非 0 解を持つための以下の条件式によって、3 種類の限界を見いだせる。

$\begin{array}{lll}\text { 構面内挙動限界条件 (対称) } & : & \lambda_{1}^{f o}\left(\tilde{\mathbf{K}}_{G^{\prime}}^{f o}\right)=0 \\ \text { 対称限界条件 } & : & \lambda_{1}^{b i}\left(\tilde{\mathbf{K}}_{G^{\prime}}^{b i}\right)=0 \\ \text { 構面内挙動限界条件 (逆対称) : } & \lambda_{1}^{b o}\left(\tilde{\mathbf{K}}_{G^{\prime}}^{b o}\right)=0\end{array}$

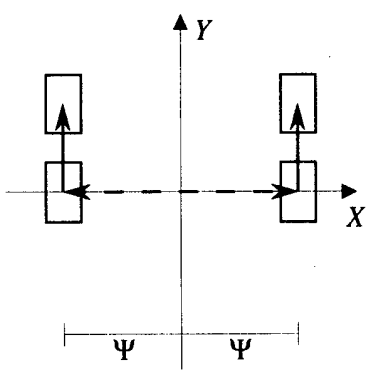

(a)対称な構面外変位

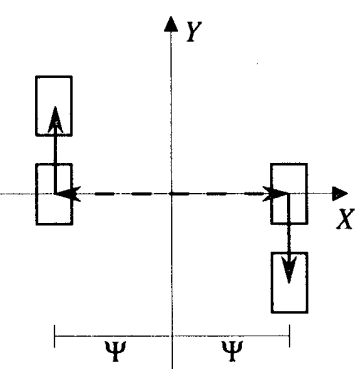

(b) 逆対称の構面外変位
図 6 構面内挙動限界における構面外変位の発生

ここに、 $\tilde{\mathbf{K}}_{G^{\prime}}^{f o} 、 \tilde{\mathbf{K}}_{G^{\prime}}^{b i} 、 \tilde{\mathbf{K}}_{G^{\prime}}^{b o}$ は $\tilde{\mathbf{K}}_{G}^{f o} 、 \tilde{\mathbf{K}}_{G}^{b i} 、 \tilde{\mathbf{K}}_{G}^{b o}$ から変位指定成 分に対応する行と列を取り除いた小行列をそれぞれ表す。また、 $\lambda_{1}^{f o} 、 \lambda_{1}^{b i} 、 \lambda_{1}^{b o}$ は、それぞれの小行列の最小固有值を表す。

従って、式 (41) が満たされる振幅 $\Psi_{i n p}^{f o}$ 、式 (42) が満たされ る振幅 $\Psi_{s y m}^{b i}$ および式 (43) が満たされる振幅 $\Psi_{i n p}^{b o}$ のうち、最 小值を与えるものによって限界の形式が定まる。

式 (41) で見いだされる限界は、直交対称面に関して対称な構 面外変位成分が発生する構面内挙動限界である(図 3 )。これに 対して、式 (43)で見いだされる限界はもう一種の構面内挙動限 界であり、この場合、 $X-Y$ 平面において第 1 象限から第 3 象 限へ、あるいは第 2 象限から第 4 象限への繰り返し挙動を呈す る構面外変位が発生する。構面内挙動限界における頂点での構 面外変位発生の㥞子を図 6 に示す。眓中、破線で示した矢印は COIDAに従う強制繰り返し変位を表し、実線の矢印は構面内挙 動限界において発生する構面外変位成分を表す。

式 (42)で見いだされる限界はいわゆる対称限界であり、構面 内での挙動を呈し続けるものの、両反転時におけるたわみ形状の 直交対称面に関する対称性が破れる。

ここでは、対称限界に至る前に構面内挙動限界 (対称) に至る ような場合について考える。

式 (26),(27) を梁-柱全体について重ね合わせて 2 組の系方程 式をつくる。

$$
\begin{aligned}
& \text { 対称成分 }: \dot{\mathbf{F}}_{G}^{f}=\tilde{\mathbf{K}}_{G}^{f} \dot{\mathbf{U}}_{G}^{f} \\
& \text { 逆対称成分： } \dot{\mathbf{F}}_{G}^{b}=\tilde{\mathbf{K}}_{G}^{b} \dot{\mathbf{U}}_{G}^{b}
\end{aligned}
$$

式 (44) を境界条件の下に解き、構面外対称定常状態の増分解を 求め、これを累加していくことにより構面外対称定常状態経路を 追跡できる。対称限界条件が满たされない限り構面内挙動限界後 も直交対称面に関して対称な挙動を呈することが保証されるの で、増分解析を続行できる。この場合の対称限界条件は次式のよ うになる。

$$
\text { 対称限界条件 } \quad \lambda_{1}^{b}\left(\tilde{\mathbf{K}}_{G^{\prime}}^{b}\right)=0
$$

ここに、 $\tilde{\mathbf{K}}_{G^{\prime}}^{b}$ は $\tilde{\mathbf{K}}_{G}^{b}$ から変位指定成分に対応する行と列を取り 除いた小行列を表し、 $\lambda_{1}^{b}$ は、その最小固有值を表す。

定常状態限界は、制御变位振幅 $\Psi$ が極大值をとる点として求 められる。定常状態経路の経路パラメターとしては、経路の進行 に伴って顕著な変化を示す量を選ぶ。この場合は、頂点構面外変 位 $V_{T}^{f}$ を選ぶのが妥当である。

なお、対称限界に早期に至る場合についても、限界後の経路 の追跡が同様に行うことができ、定常状態限界を求めることがで きる8)。 


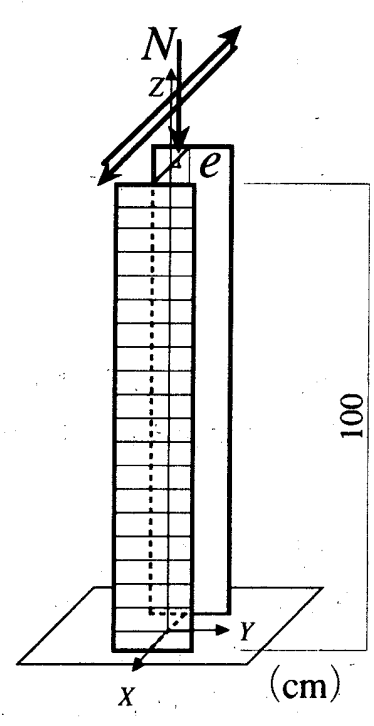

図 $7 \mathrm{H}$ 形鋼片持梁-柱モデル

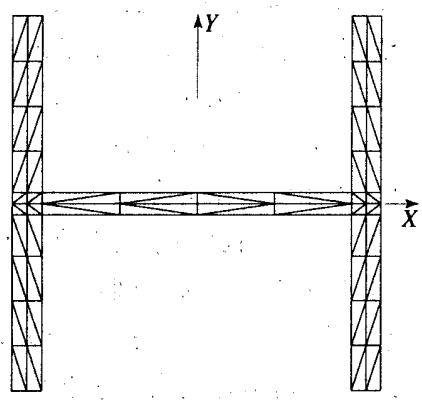

図 8 . 要素断面

\section{4. 例題}

ここでは、図 7 に示す $\mathrm{H}$ 形鋼片持梁-柱を解析対象モデルと し、その強軸方向に頂点に COIDAを作用させる問題を考える。 鋼材モデルは、H-100 × $100 \times 6 \times 8$ をモデル化し、材軸方向に 20 要素に等分割する。各要素は、図 8 に示すように 96 の三角柱 領域に分割する。断面と材料特性に関する諸量を表 2 に示す。

このモデルの降伏軸力は， $N_{Y}=6.186 \times 10^{2}(\mathrm{kN})$ となる。ま た、頂点の $X$ 方向変位だけを拘束しその他の変位は自由である片 持梁-柱の接線係数荷重は強軸側で $N_{T y}=4.602 \times 10^{2}(\mathrm{kN})$ 、弱 軸側で $N_{T x}=2.033 \times 10^{1}(\mathrm{kN})$ となる。対称限界理論より $N_{T y}$ 以下の軸力レベルでは対称限界には至らず6,7)、構面内挙動限界

\section{:表 2 断面諸量と材料特性}

\begin{tabular}{lll}
\hline 断面積 & $A$ & $2.104 \times 10^{1}\left(\mathrm{~cm}^{2}\right)$ \\
断面 2 次 & $I_{x}$ (弱軸) & $1.335 \times 10^{2}\left(\mathrm{~cm}^{4}\right)$ \\
モーメント & $I_{y}$ (強軸) & $3.690 \times 10^{2}\left(\mathrm{~cm}^{4}\right)$ \\
ヤング係数 & $E$ & $2.058 \times 10^{2}(\mathrm{GPa})$ \\
ポアソン比 & $\nu$ & $3.000 \times 10^{-1}$ \\
降伏応力 & $\sigma_{Y}$ & $2.940 \times 10^{2}(\mathrm{MPa})$ \\
第 2 分枝勾配 & $E_{t}$ & $6.174 \times 10^{0}(\mathrm{GPa})$ \\
\hline
\end{tabular}

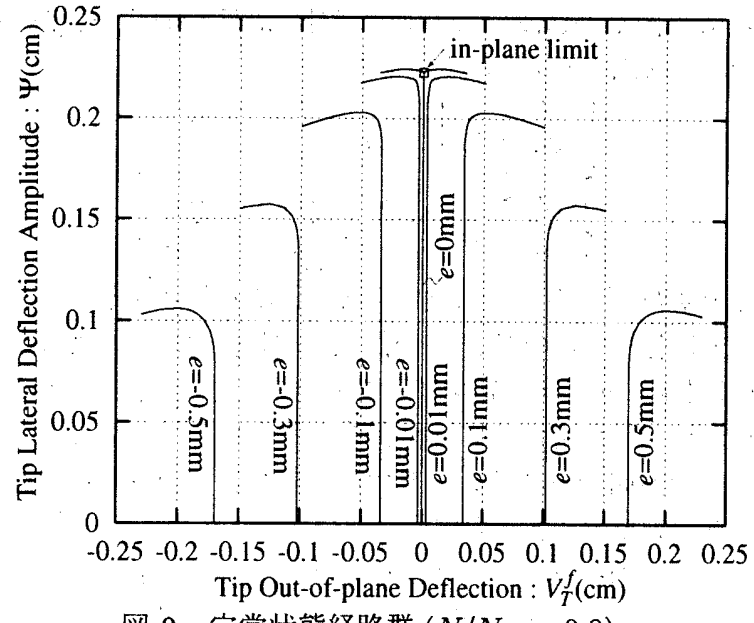

図 9 定常状態経路群 $\left(N / N_{Y}=0.8\right)$

理論より $N_{T x}$ 以下の軸カレベルでは構面内挙動限界には至らな ( $^{5)}$ 。

\section{1 軸力比 0.8 の場合}

軸力比 0.8 、すなわち鉛直荷重が $494.9 \mathrm{kN}$ 作用している場合 について解析を行う。

前章で定式化した解析法に従って各限界振幅を求めた結果、 $\Psi_{i n p}^{f o}=2.225 \mathrm{~mm} 、 \Psi_{s y m}^{b i}=21.66 \mathrm{~mm} 、 \Psi_{i n p}^{b o}=11.11 \mathrm{~mm}$ と なった。従って構面内挙動限界 (対称) に早期に至ることがわ かる。

構面内挙動限界点において、分岐モードの方向への増分解析 を行う。このとき、定常状態経路解析のための方程式を式 (44) に変更しておく。分岐後の定常状態経路を正しく得るため、整合 剛性行列形成法 ${ }^{14)}$ を用いて解析を行う。具体的には、まず限界 点において $\lambda_{1}^{f o}$ に対応する固有モード $\Phi_{1}^{f o}$ を求める。次に $\Phi_{1}^{f o}$ の方向の変化率を与えた場合の各要素のひずみ変化率を求め、こ れに整合する係数 $\tilde{D}$ を選択する。そして、経路パラメターとし て頂点構面外変位 $V_{T}^{f}$ を選び増分解析を行えば、定常状態経路を 求めることができる。また、一 $\Phi_{1}^{f o}$ の方向へも同様の解析を行う ことにより、もう一方の定常状態経路も求めることができる。

解析の結果、整合解としては制御変位振幅 $\Psi$ が増加する方向 への解が得られた。従って、構面内挙動限界後には構面外定常状 態が存在することがわかる。

分岐後の構面外定常状態経路解析においては、式 (46)によっ て、モデルが対称限界に至るかどうかを常にチェックする。対 称限界に至る前に定常状態経路が極限点を迎えたならば、それ が定常状態限界である。分岐後経路解析の結果、その後 $\Psi$ の わずかな増加の後、定常状態限界に至り、定常状態限界振幅は $\Psi_{s t 0}=2.244 \mathrm{~mm}$ となった。

既往の座屈後経路解析法では、なめらかな経路解析を行うた め、あらかじめ座屈モードの方向への微小な初期不整を与えるこ とにより分岐点である座屈点を避ける方法が一般的によく用いら れる。座屈後経路解析法と同じ考えに基づき、ここでも、構面外 方向への対称な微小初期不整を与之、定常状態経路解析を行う。

対称な初期不整として、軸力偏心を構面外方向へ与えること とし、同じモデルに種々の軸力偏心量 $e$ を㝋て定常状態経路解 析を行った。解析結果として、制御変位振幅 $\Psi$ と頂点構面外変 位 $V_{T}^{f}$ との関係を図 9 に示す。 


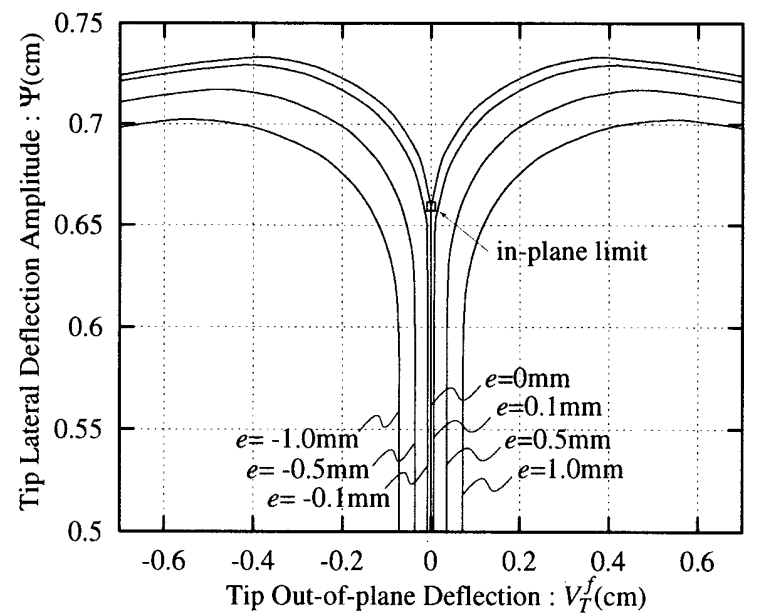

図 10 定常状態経路群 $\left(N / N_{Y}=0.4\right)$

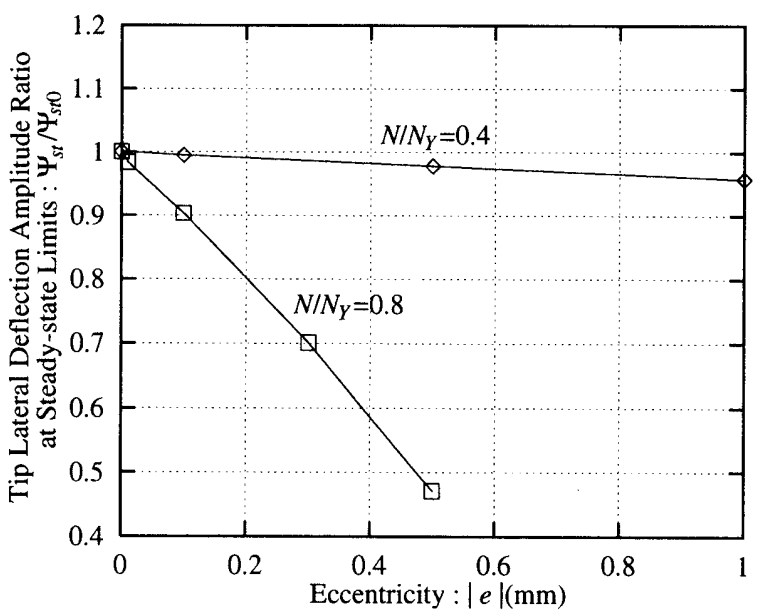

図 11 軸力偏心量-定常状態限界振幅関係

\section{2 軸力比 0.4 の場合}

軸力比 0.4 、すなわち鉛直荷重が $247.4 \mathrm{kN}$ 作用している場合 について解析を行う。

構面内挙動限界を求めた結果、 $\Psi_{i n p}^{f o}=6.592 \mathrm{~mm} 、 \Psi_{i n p}^{b o}=$ $10.97 \mathrm{~mm}$ が得られた。この軸力比では対称限界には至らないの で、構面内挙動限界 (対称)に早期に至ることがわかる。

構面内挙動限界における構面外方向への整合解としては、頂 点変位振幅が増加する方向への解が得られた。分岐後経路解析の 結果、定常状態限界振幅は $\Psi_{s t 0}=7.333 \mathrm{~mm}$ となった。

軸力比 0.8 の場合と同様に、種々の軸力偏心量 $e$ を構面外方 向へ与えたモデルについて定常状態経路解析を行った。解析結果 として、制御変位振幅 $\Psi$ と構面外変位 $V_{T}^{f}$ との関係を図 10 に 示す。

また、それぞれの軸力比について、軸力偏心量の大きさ $|e|$ の 増加に対する定常状態限界振幅 $\Psi_{s t}$ の変化を見るため、軸力偏 心が無い場合の值 $\Psi_{s t 0}$ に対する比をとった結果を図 11 に示す。 $|e|$ の増加に対して定常状態限界振幅 $\Psi_{s t}$ は線形的に減少し、軸 力が大きいほど減少の割合も大きいことがわかった。

\section{5. 履歴挙動解析}

理論解を検証するため、軸力比 0.8 および軸力比 0.4 のそれぞ れの場合について、同じ軸力載荷条件のもと、一定の頂点 $X$ 方 向強制変位振幅での繰り返し両振り曲げ履歴挙動解析を行う。

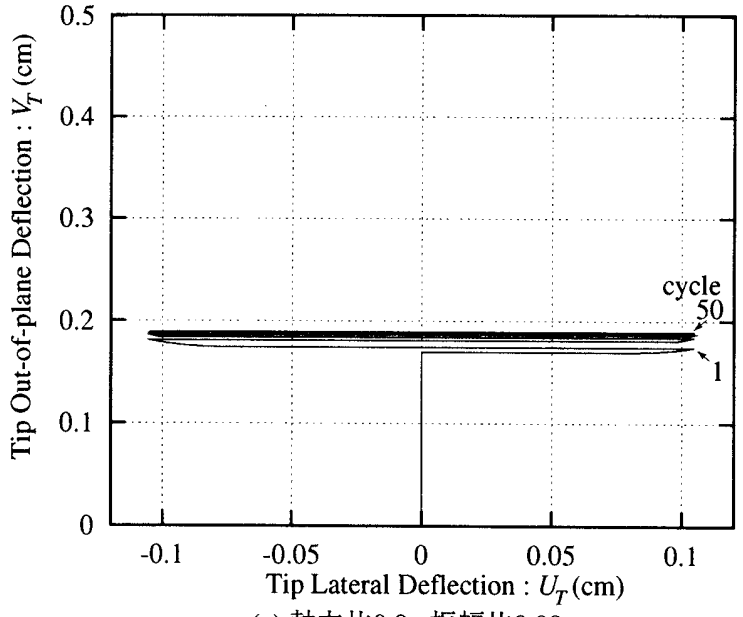

(a) 軸力比 0.8 : 振幅比 0.99

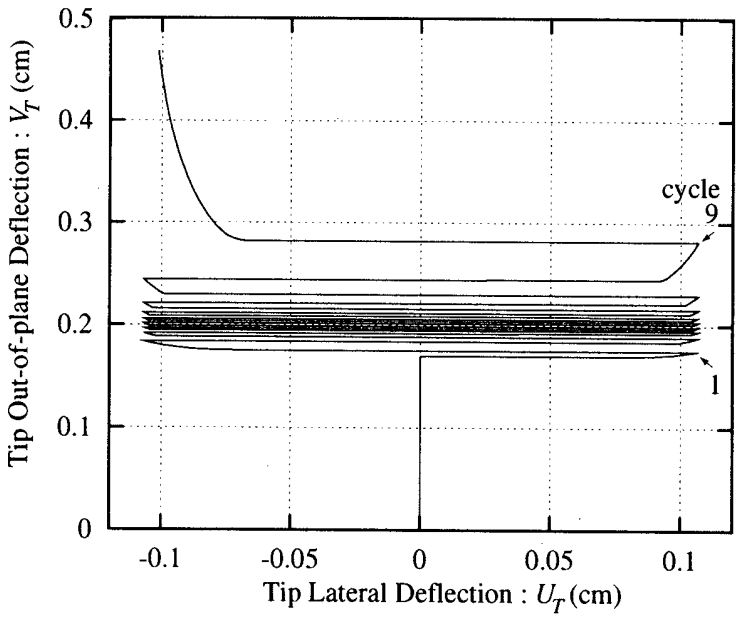

(b) 軸力比 0.8 : 振幅比 1.01

図 12 載荷節点変位-構面外変位関係 $\left(N / N_{Y}=0.8\right)$

\section{1 軸力比 0.8 の場合}

軸力偏心を $0.5 \mathrm{~mm}$ 与えたモデルについて検証する。理論解析 により予測された定常状態限界振幅は $\Psi_{s t}=1.057 \mathrm{~mm}$ であっ た。ここでは、0.99 $\Psi_{s t}$ および $1.01 \Psi_{s t}$ の一定頂点 $X$ 方向強制 変位振幅を設定し、繰り返し載荷を行う。

履歴挙動解析結果として、頂点 $X$ 方向変位 $U_{T}$ と頂点構面外変 位 $V_{T}$ の関係を図 12 に示す。(a) は頂点 $X$ 方向変位振幅 $0.99 \Psi_{s t}$ の場合、(b)は $1.01 \Psi_{s t}$ の場合である。0.99 $\Psi_{s t}$ の場合、梁-柱は 直ちにシェイクダウン状態に至り、収束挙動を示した。理論解析 によるこの場合の頂点構面外変位は $V_{T}^{f}=1.893 \mathrm{~mm}$ であるのに 対して、履歴解析による収束値は $V_{T}=1.891 \mathrm{~mm}$ と、精度良い 結果が得られている。

これに対して $1.01 \Psi_{s t}$ の場合、挙動は収束せず、繰り返し載 荷の進行に伴い構面外変形が進行し、発散挙動に至ることがわ かる。

\section{2 軸力比 0.4 の場合}

軸力偏心を $0.1 \mathrm{~mm}$ 与えたモデルについて検証する。定常状態 経路解析の結果、定常状態限界振幅は、 $\Psi_{s t}=7.296 \mathrm{~mm}$ であり、 このときの構面外変位は $V_{T}^{f}=4.174 \mathrm{~mm}$ となった。

一定頂点 $X$ 方向強制変位振幅として、0.99 $\Psi_{s t} 、 1.01 \Psi_{s t}$ 、 $1.03 \Psi_{s t}$ および $1.05 \Psi_{s t}$ を設定し、それぞれについて 50 サイ クルまでの繰り返し載荷を行なった。 


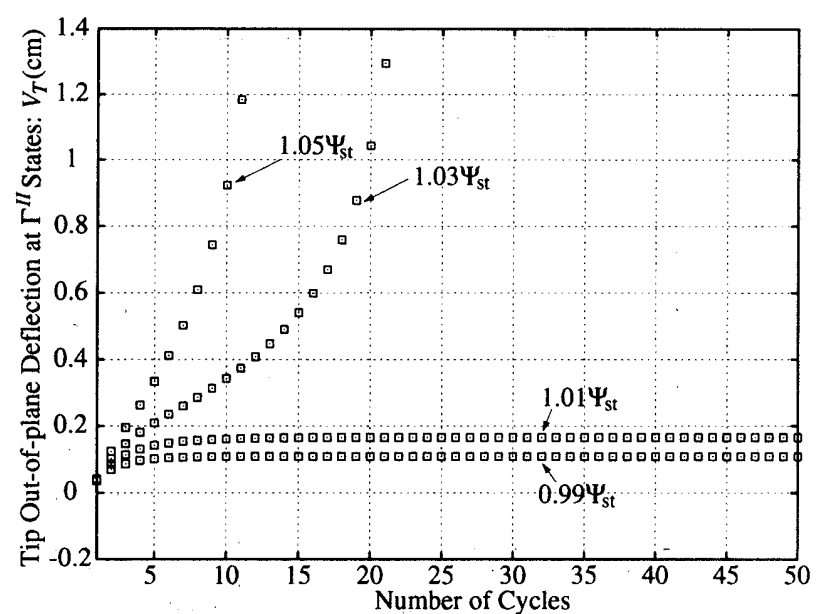

図 13 載荷サイクル数-頂点構面外変位関係 $\left(N / N_{Y}=0.4\right)$

履歴挙動解析結果として、繰り返し載荷のサイクル数と頂点構 面外変位 $V_{T}$ の関係を図 13 に示す。 $0.99 \Psi_{s t 、 1.01 \Psi_{s t}}$ の場合、 構面外定常状態への収束傾向が見受けられるが、両者ともシェイ クダウシには至っておらず、構面外変形はわずかずつ增大を続け ている。今後、構面外変位は理論予測値付近までは増大を続け、 その後に収束、発散に挙動が分かれると予想される。

$1.03 \Psi_{s t}$ 以上の振幅の場合、振幅が大きいほどサイクル数の増 加に伴う構面外変位の累積が顕著となり、いずれの場合も発散挙 動に至った。以上より、理論予測解は良好な精度で得られている ものと判断できる。

\section{6. 結論}

完全両振り繰り返し曲げを受ける二軸対称断面梁-柱について、 定常状態限界を求めるための解析法を提示した。その主な成果お よび特長は次の通りである。

1）離散化モデルとして、Timoshenko 梁理論のせん断変形と、 ねじれ変形を共に考慮した有限要素法を採用し、移動要素 座標系によって三次元空間内の要素の有限回転を厳密に扱 える方法を用いた。

2）定常状態経路の增分解析の基礎式である定常状態変化率方 程式を導いた。

3）系が有する 2 種類の異なる対称性に着目し、構面内対称定 常状態に扔ける定常状態変化率方程式が 4 組の独立な方程 式群に分解できることを証明した。

4) その内の 3 組の斉次方程式群の特異性条件 (singularity condition) から、定常状態経路の分岐点として構面内挙動限界 および対称限界がそれぞれ求まる。

5）定常状態経路を追跡し、その極限点として定常状態限界が 求まる。

本解析法を適用し、強軸方向に繰り返し曲げを受ける $\mathrm{H}$ 形鋼 片持梁-柱を対象とし、定常状態経路および定常状態限界を予測 した。解析を行なった全ケースで、構面内挙動限界が最初に現わ れ、その後更に振幅が増加したところで定常状態限界に達した。

本解析法を検証する目的で、同じ $\mathrm{H}$ 形鋼片持梁-柱に一定振幅 繰り返し曲げを与えたときの全履歴挙動を追跡する解析を行な い、予測限界值前後の振幅で挙動が取束と発散に分かれることを 示した。これによって、本解析法の妥当性が確認された。
注 1) 3.3 節で定義される構面内成分と構面外成分をあらかじめ意識して、式 $(2)$ の変位ベクトルを定義しているので、変位成分の順序が文献 5)で定義し たものと異なっている。

注 2）線形增分型の解析では、適切な增分長の值について何らの情報も得られな いので、精度を保証するためには、各增分段階での収束計算を行うか、よ り高階の微係数の関係を求めて摂動解析を行うのが一般的である。本論文 では、数回の予借解析を行うことにより、適切な增分長を設定している。 例题では、有効数字 4 析の精度を保証するために、各增分段階において、 全ての要素のひずみ变化率の絶対值が $10^{-4}$ を越えないように增分辰を設 定している。

注 3）線形增分解析および有限要素法による離散化のため、関数の値は不連続と なるが、このことは関数の連続性の議論には影響を及はさない。

参考文献

1) 若林實 編著：鉄骨構造学詳論, 丸善, 1985

2），中村恒善，上谷宏二，吉田亘利：繰り返し曲げを受ける龬梁-柱における梙面 外変形の発生に関する実験，日本建築学会大会学術講演梗概集 (関東) 構造 II, pp.1075-1076, 1988 .

3）上谷宏二, 中村恒善, 今井敬, 吉田亘利: 絽り返し曲げを受ける錳構造柱材の 構面外変形の発生と成長に関する実験的研究 (その 1)，日本建築学会大会学 術講演梗概集 (関東) 構造 II, pp.1331-1332, 1993.

4) 上谷宏二, 中村恒善, 常岡次郎：繰り返し闻捺り曲げを受ける片持梁-柱につ いての構面外変形発生機構と臣界点理論，日本建築学会大会学術講演梗概集 (関東) 構造 II, pp.1077-1078, 1988

5）上谷宏二, 树井 健：繰り返し曲げを受ける片持梁-柱の構面内挙動限界解析 法，日本建築学会構造系論文集，第 513 号, pp.97-104, 1998.

6) K.Uetani and Tsuneyoshi Nakamura : Symmetry limit theory for cantilever beam-columns subjected to cyclic reversed bending, $J$. Mech. Pys. Solids, Vol.31, pp.449-484, 1983.

7）上谷宏二：繰返し両振り曲げを受ける弾塑性梁-柱についての対称限界理諭と 定常状態限界理論, 京都大学博士諭文, 1984 .

8）上谷宏二，中村恒善：繰り返し両振り曲げを受ける片持梁-柱の定常状態限界 理諭（その1），日本建築学会棈造系論文報告集，第 438 号，pp. 105-115, 1992.8 .

9）藤本盛久，和田 章，岩田 衛，中谷文俊: 銅構造骨組の三次元非線形解析，日 本建築学会構造系論文報告集，第 227 号, pp. 75-90, 1975.1.

10）修行稔: 权じりと曲げを受ける薄肉閉断面材の弾塑性挙動，日本建築学会構 造系論文報告集，第 436 号，pp. 145-154，1992.6.

11）藤谷義信: 骨組構造の力学, 建築構造力学の最近の発展 -応力解析の考方方-, 日本建築学会, 3.1, 1987.

12）上谷宏二: ティモシェンコ梁の有限要素剛性方程式誘導のための縮約法，構 造工学論文集, Vol. $39 \mathrm{~B}$, pp. $65-72,1993$.

13) R. Hill: A General Theory of Uniqueness and Stability in Elasticplastic Solids, J. Mech. Pys. Solids, Vol.6, pp.236-249, 1958.

14）上谷宏二, 中村恒善, 森迫清貴, 石田修三：弾塑性構造物の臨界举動解析のた めの整合剛性行列形成法，日本建築学会構造系論文集, 第 445 号, pp.67-78, 1993.12.

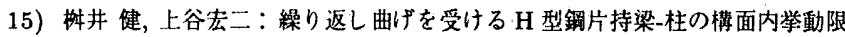
界および定常状態限界，日本建築学会大会学術講演梗概集（近畿）棈造 I pp.415-416, 1996.

16）上谷宏二, 桝井 健：繰り返し両振り曲げを受ける龬梁-柱の構面内举動限界扝 よび定常状態限界, 日本機会学会平成 8 年度材料力学部門講演会諩演論文集, Vol. A, pp.295-296, 1996.

17）上谷宏二，拸井 健：繰り返し曲げを受ける，立体骨組部材の構面内举動限界およ び定常状態限界，計算工学講演会論文集，Vol.3，No.3，pp.781-784，1998.

(1998年 9 月 9 日原稿受理, 1999年 1 月 27 日採用決定） 